\title{
Global Positioning System (GPS) Survey of Augustine Volcano, Alaska, August 3-8, 2000: Data Processing, Geodetic Coordinates and Comparison with Prior Geodetic Surveys
}

\author{
Benjamin A. Pauk ${ }^{1}$, John A. Power ${ }^{2}$, Mike Lisowski ${ }^{3}$, Dan Dzurisin ${ }^{3}$, \\ Eugene Y. Iwatsubo ${ }^{3}$, and Tim Melbourne ${ }^{1}$
}

\footnotetext{
${ }^{1}$ Department of Geological Sciences, Central Washington University, Ellensberg, WA, 98926

2 Alaska Volcano Observatory, U.S. Geological Survey, 4200 University Dr., Anchorage, AK 99508

${ }^{3}$ U.S. Geological Survey, Cascades Volcano Observatory, 5400 Macarthur Blvd., Vancouver, WA 98661
}

This report is preliminary.

Any use of trade, product or firm names is for descriptive purposes only and does not imply endorsement by the U.S. Geological Survey.

Open-File Report 01-99 


\section{Introduction}

Between August 3 and 8, 2000, the Alaska Volcano Observatory completed a Global Positioning System (GPS) survey at Augustine Volcano, Alaska. Augustine is a frequently active calcalkaline volcano located in the lower portion of Cook Inlet (fig. 1), with reported eruptions in 1812, 1882, 1909?, 1935, 1964, 1976, and 1986 (Miller et al., 1998). Geodetic measurements using electronic and optical surveying techniques (EDM and theodolite) were begun at Augustine Volcano in 1986. In 1988 and 1989, an islandwide trilateration network comprising 19 benchmarks was completed and measured in its entirety (Power and Iwatsubo, 1998). Partial GPS surveys of the Augustine Island geodetic network were completed in 1992 and 1995; however, neither of these surveys included all marks on the island. Additional GPS measurements of benchmarks A5 and A15 (fig. 2) were made during the summers of 1992, 1993, 1994, and 1996.

The goals of the 2000 GPS survey were to: 1) re-measure all existing benchmarks on Augustine Island using a homogeneous set of GPS equipment operated in a consistent manner, 2) add measurements at benchmarks on the western shore of Cook Inlet at distances of 15 to $25 \mathrm{~km}, 3$ ) add measurements at an existing benchmark (BURR) on Augustine Island that was not previously surveyed, and 4) add additional marks in areas

of the island thought to be actively deforming. The entire survey resulted in collection of GPS data at a total of 24 sites (fig. 1 and 2).

In this report we describe the methods of GPS data collection and processing used at Augustine during the 2000 survey. We use this data to calculate coordinates and elevations for all 24 sites surveyed. Data from the 2000 survey is then compared to 
electronic and optical measurements made in 1988 and 1989. This report also contains a general description of all marks surveyed in 2000 and photographs of all new marks established during the 2000 survey (Appendix A).

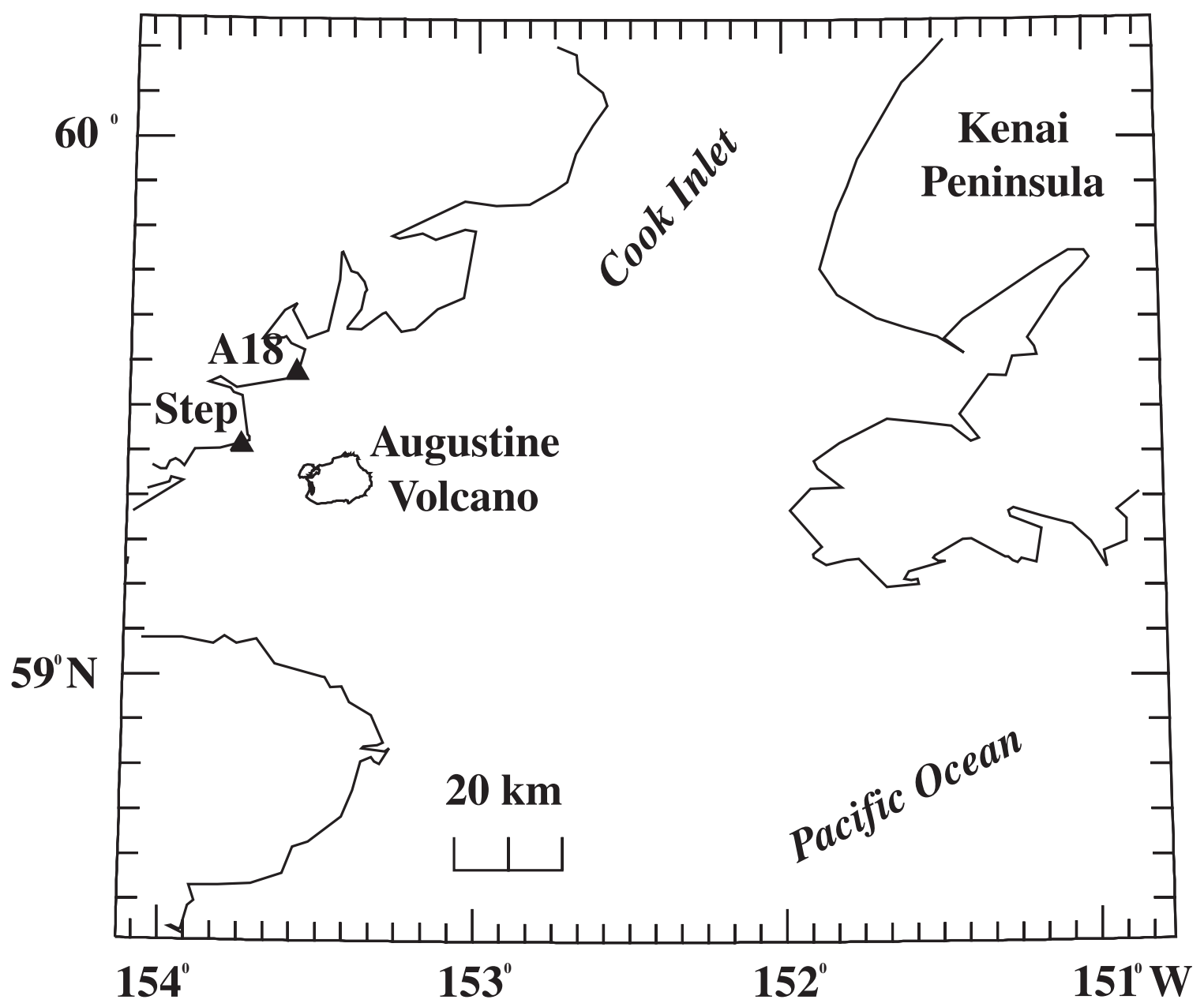

Figure 1. Augustine Volcano is located on a small island in southern Cook Inlet, Alaska. Locations of benchmarks Step and A18 on the western side of Cook Inlet are shown as triangles. 


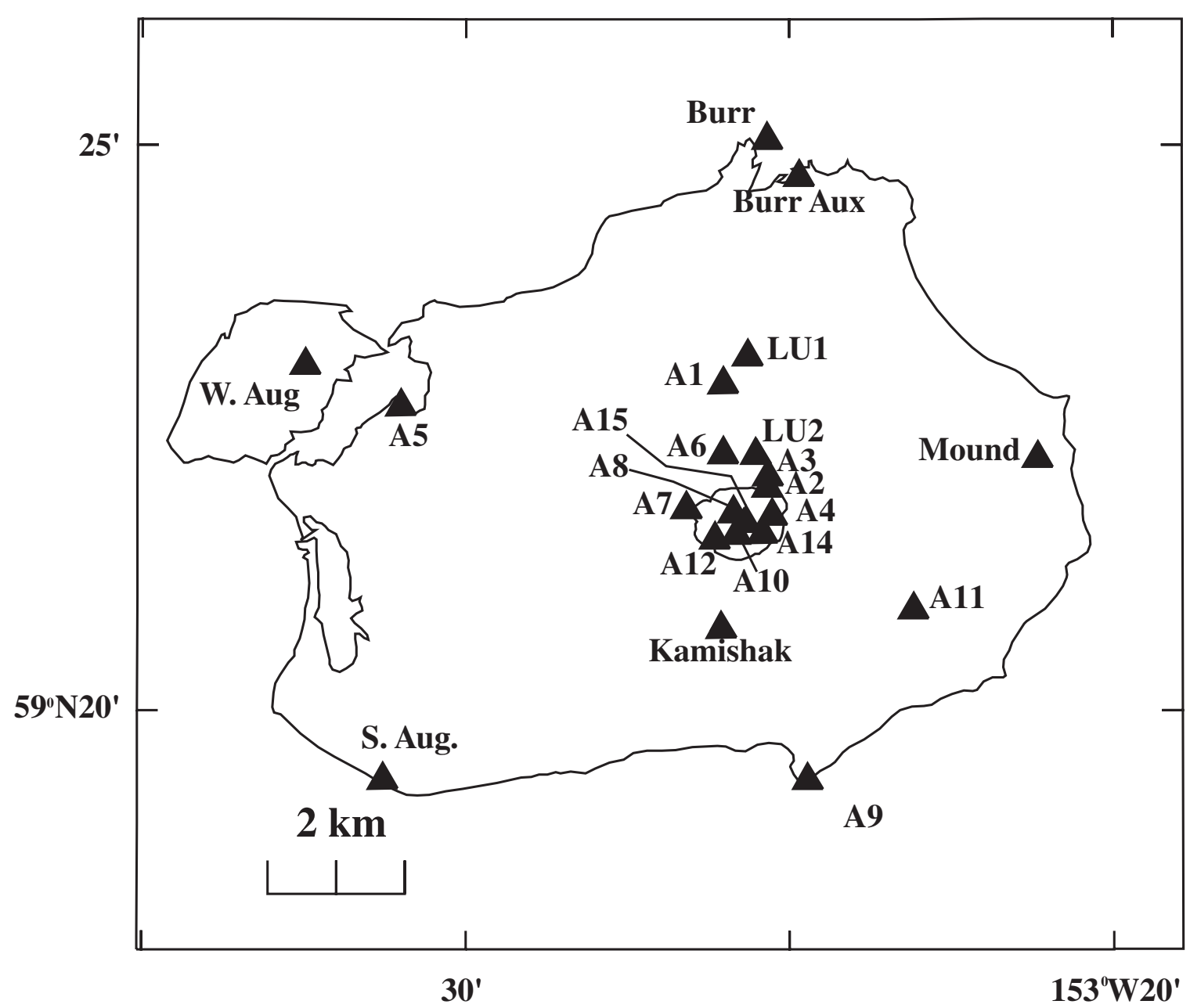

Figure 2. Triangles note approximate locations of benchmarks on Augustine Island surveyed between August 3 and 8, 2000.

\section{Acknowledgements}

The 2000 GPS survey at Augustine Island was a cooperative effort involving personnel and equipment from the Alaska Volcano Observatory, USGS Cascades Volcano Observatory, and the Department of Geological Sciences, Central Washington University (CWU). Prof. Meghan Miller of CWU kindly loaned us the majority of the GPS equipment used for the survey. Dave Schneider, Tom Murray, John Paskievitch, and Dan Johnson helped with logistics. Kachemak Air Service, Maritime Helicopters and helicopter pilot Bill Springer provided safe and efficient transportation for personnel and 
equipment. The authors gratefully acknowledge all of these contributions that helped make the 2000 survey a success.

\section{Survey Methods and Data Processing}

All stations from the 1988 and 1989 surveys were recovered in good condition. Station A10, however, was partially surrounded by en-echelon cracks with up to $5 \mathrm{~cm}$ of opening and its stability is suspect. Station A14 was secured with additional cement. We added station BURR, established in 1913, and three new marks during the 2000 survey (A18, LU01 and LU02), as well as STEP that was also surveyed in 1992 and 1993.

During 1995 several offset stations were installed on the volcano near benchmarks A3, A4, A6, A7, A10 and A12. These offset stations consisted of a central screw that allowed direct mounting of the GPS antenna. These offset stations were not included in the 2000 survey.

The 2000 GPS survey of Augustine was conducted with Trimble 4000 SSi receivers and Trimble Choke Ring antennas provided by the Department of Geological Sciences, Central Washington University (CWU) and the USGS Cascades Volcano Observatory (CVO). The antennas were mounted on tripods, centered either with optical plummets or self-centering rods and oriented to true north with a Brunton compass. All receivers were programmed to record satellite phase and pseudorange data every 30 seconds, with the minimum number of satellites set to one and the minimum recording elevation set to ten degrees. Power was supplied to the receivers by 12-volt 100 amp-hour batteries. These batteries provided the receivers with enough power to continuously record data for up to 72 hours. Our goal was to collect 24 hours of continuous data at 
each mark. The actual amount of recorded data actually varied from about 6.5 hours at West Augustine to as much as three days at some high elevation stations where inclement weather precluded retrieval for several days.

The 2000 Augustine GPS data were first processed at the Pacific Northwest Geodetic Array (PANGA) Data Analysis Facility at CWU using standard practices detailed in Miller and others (submitted). Discrepancies were found in the comparison with earlier EDM measured distances, particularly in lines from station West Augustine. In an effort to resolve these problems, independent data reduction was done using the USGS gp data processing environment developed by William Prescott. To make use of this processing system new station names were assigned in the rinex files. A table summarizing these changes is contained in Appendix B. The 6.5 hours of reliable data recorded at West Augustine spanned two UTC days and the PANGA processing divided the data between the days. In the USGS processing, data files that extend a few hours before or after the UTC day boundary were merged and processed with the adjacent larger file. This appeared to significantly improve the solutions, particularly at West Augustine. Differences between the PANGA and USGS processing at other stations were minor.

The PANGA and USGS gp GPS data processing both use the NASA s Jet Propulsion Laboratory (JPL) GPS Inferred Positioning System/Orbit Analysis and Simulation Software (GIPSY/OASIS II). Daily solutions for station site positions were determined within the 1997 International Reference Frame (ITRF97). Daily solutions were merged to provide adjusted geodetic coordinates for all sites surveyed in 2000 
(Table 1). Mark-to-mark slope distances were extracted from the adjusted network solution for comparison with earlier EDM surveys (Table 2).

We have made GPS raw and RINEX data files, copies of field notes from the 2000 survey, and the text from this report available for download.

\section{Results}

Mark-to-mark slope distances determined by the 2000 GPS survey and the 1988 and 1989 EDM surveys (Power and Iwatsubo, 1998) are compared in Table 2. For this comparison, we have averaged the 1988 and 1989 measurements. For this preliminary analysis, we call the reader s attention to just those results that differ by more than an arbitrary threshold of $5 \mathrm{~cm}$. Smaller changes may well be significant, but their interpretation requires additional work that will be reported elsewhere.

Of the 30 mark-to-mark slope distances measured in 1988 and 1989, 24 differ by less than $5 \mathrm{~cm}$ from the 2000 GPS results. Among the remaining 6 distances, the largest discrepancy was from station South Augustine to station A10. Station A10 is located high on the 1964 lava dome and fresh cracks were observed around it during the 2000 occupation, suggesting that it may be unstable. The 1995-2000 differences between BURR AUX and A15, and between Mound and A15, were also larger than $5 \mathrm{~cm}$. A15 is located on a portion of the 1986 lava dome that is known to have subsided approximately $50 \mathrm{~cm}$ and moved slowly to the west since 1992. This subsidence is monitored by a telemetered GPS system (Murray and others, 1996) and GPS measurements between mark A5 and A15 made in 1992, 1993, 1994, 1996, and 2000. We attribute this subsidence to movement of a large landslide block on the north side of the 1986 lava 
Table 1. Geodetic Coordinates for the Augustine Volcanic Deformation Network Determined With GPS during August 2000.

\begin{tabular}{|l|l|l|c|}
\hline Station & $\begin{array}{l}\text { Longitude } \\
\text { (Degrees) }\end{array}$ & $\begin{array}{l}\text { Latitude } \\
\text { (Degrees) }\end{array}$ & $\begin{array}{l}\text { Radius Height } \\
\text { (ITRF97) }\end{array}$ \\
\hline A1 & -153.4378166 & 59.38155618 & 355.1804 \\
\hline A2 & -153.4245071 & 59.36662192 & 879.2775 \\
\hline A3 & -153.4243476 & 59.36762362 & 865.1927 \\
\hline A4 & -153.4234686 & 59.36236908 & 1055.7675 \\
\hline A5 & -153.5192277 & 59.37812122 & 28.9097 \\
\hline A6 & -153.4373268 & 59.37117941 & 677.1183 \\
\hline A7 & -153.4456606 & 59.36306881 & 900.5171 \\
\hline A8 & -153.4330946 & 59.36244693 & 1218.5432 \\
\hline A9 & -153.4139848 & 59.32300273 & 40.8022 \\
\hline A10 & -153.4327076 & 59.35932923 & 1243.1684 \\
\hline A11 & -153.3867686 & 59.34864969 & 216.8437 \\
\hline A12 & -153.4377613 & 59.35869477 & 1100.5371 \\
\hline A14 & -153.4258876 & 59.35939555 & 1179.8655 \\
\hline A15 & -153.4282898 & 59.36171392 & 1224.1582 \\
\hline A18 & -153.5877955 & 59.57006497 & 394.8782 \\
\hline BURR & -153.4224428 & 59.41793856 & 27.8131 \\
\hline Burr. Aux. & -153.4164213 & 59.4118784 & 27.5035 \\
\hline KAMISHAK & -153.4365566 & 59.34565958 & 530.828 \\
\hline MOUND & -153.4273294 & 59.38592345 & 246.2074 \\
\hline W. Augustine & -153.4250452 & 59.3718602 & 558.7879 \\
\hline S. Augustine & -153.3550602 & 59.37068949 & 118.2671 \\
\hline STEP & -153.7648384 & 59.43431333 & 433.939 \\
\hline LU01 & -153.4273287 & 59.38592414 & 246.193 \\
\hline LU02 & -153.4250445 & 59.37186088 & 558.774 \\
\hline
\end{tabular}


Table 2. Comparison of average line lengths measured in 1988 and 1989 with calculated 2000 line lengths.

\begin{tabular}{|c|c|c|c|c|c|}
\hline LINE & 1988 (m) & 1989 (m) & $\begin{array}{l}\text { 1988-1989 } \\
\text { AVERAGE }\end{array}$ & $2000(\mathrm{~m})$ & $\begin{array}{c}\text { DIFFERENCE } \\
\text { (m) }\end{array}$ \\
\hline $\begin{array}{l}\text { W.Aug- } \\
\text { A1 }\end{array}$ & 6014.5365 & 6014.5320 & 6014.53425 & 6014.5481 & +0.0138 \\
\hline $\begin{array}{l}\text { W.Aug- } \\
\text { A3 }\end{array}$ & 7067.1485 & ------------ & 7067.1485 & 7067.1331 & -0.0154 \\
\hline $\begin{array}{l}\text { W.Aug- } \\
\text { A5 }\end{array}$ & 1540.1411 & 1540.1389 & 1540.1400 & 1540.1342 & -0.0058 \\
\hline $\begin{array}{l}\text { W.Aug- } \\
\text { A6 }\end{array}$ & 6237.0521 & 6237.0548 & 6237.05345 & 6237.0979 & +0.0444 \\
\hline $\begin{array}{l}\text { W.Aug- } \\
\text { A7 }\end{array}$ & 6102.3246 & 6102.3324 & 6102.3285 & 6102.3501 & +0.0216 \\
\hline $\begin{array}{l}\text { W.Aug- } \\
\text { A8 }\end{array}$ & 6831.2637 & 6831.2637 & 6831.2637 & 6831.4226 & +0.1589 \\
\hline $\begin{array}{l}\text { W.Aug- } \\
\text { A10 }\end{array}$ & 6987.7236 & 6987.7138 & 6987.7187 & 6987.7348 & +0.0161 \\
\hline $\begin{array}{l}\text { W.Aug- } \\
\text { S.Aug }\end{array}$ & 6913.0226 & 6913.0164 & 6913.0200 & 6913.0230 & +0.0030 \\
\hline S.Aug-A7 & 6330.3207 & ------------ & 6330.3207 & 6330.3486 & +0.0279 \\
\hline $\begin{array}{l}\text { S.Aug- } \\
\text { A10 }\end{array}$ & 6658.2012 & ------------ & 6658.2012 & 6658.4228 & +0.2216 \\
\hline $\begin{array}{l}\text { S.Aug- } \\
\text { A12 }\end{array}$ & 6368.3544 & 6368.3509 & 6368.35265 & 6368.4040 & +0.0514 \\
\hline $\begin{array}{l}\text { S.Aug- } \\
\text { Kam }\end{array}$ & 5564.5635 & 5564.5677 & 5564.5656 & 5564.5778 & +0.0122 \\
\hline A9 - Kam & 2874.3693 & 2874.3480 & 2874.35865 & 2874.3508 & -0.0078 \\
\hline A9-A11 & 3254.8157 & 3254.8231 & 3254.8194 & 3254.8133 & -0.0061 \\
\hline A9-A12 & 4332.0542 & 4332.0472 & 4332.0507 & 4332.0317 & -0.0190 \\
\hline A9-A14 & 4265.6306 & 4265.6477 & 4265.63915 & 4265.6764 & +0.0372 \\
\hline $\begin{array}{l}\text { Mound-A } \\
2\end{array}$ & 4047.1403 & 4047.1374 & 4047.13885 & 4047.1481 & +0.0092 \\
\hline $\begin{array}{l}\text { Mound-A } \\
3\end{array}$ & ------------ & 4024.5919 & 4024.5919 & 4024.6068 & +0.0149 \\
\hline $\begin{array}{l}\text { Mound-A } \\
4\end{array}$ & 4107.5395 & 4107.5629 & 4107.5512 & 4107.6204 & +0.0692 \\
\hline $\begin{array}{l}\text { Mound-A } \\
11\end{array}$ & 3048.0769 & 3048.0759 & 3048.0764 & 3048.0814 & -0.0050 \\
\hline $\begin{array}{l}\text { Mound- } \\
\text { A14 }\end{array}$ & 4351.4988 & 4351.4969 & 4351.49785 & 4351.5040 & +0.0062 \\
\hline $\begin{array}{l}\text { Mound- } \\
\text { A15 }\end{array}$ & ------------- & 4423.3404 & 4423.3404 & 4423.4001 & +0.0597 \\
\hline $\begin{array}{l}\text { Burr Aux } \\
\text { - Mound }\end{array}$ & 5763.6883 & 5763.6938 & 5763.69105 & 5763.7014 & +0.0104 \\
\hline $\begin{array}{l}\text { Burr Aux- } \\
\text { A1 }\end{array}$ & 3605.0638 & 3605.0575 & 3605.06065 & 3605.0287 & -0.0320 \\
\hline
\end{tabular}




\begin{tabular}{|l|l|l|l|l|l|}
\hline $\begin{array}{l}\text { Burr Aux } \\
-\mathrm{A} 3\end{array}$ & 5021.2877 & 5021.2998 & 5021.29375 & 5021.3096 & +0.0158 \\
\hline $\begin{array}{l}\text { Burr Aux } \\
-\mathrm{A} 4\end{array}$ & 5625.1659 & 5625.2072 & 5625.18655 & 5625.1977 & +0.0112 \\
\hline $\begin{array}{l}\text { Burr Aux } \\
-\mathrm{A} 6\end{array}$ & 4732.0497 & 4732.0424 & 4732.04605 & 4732.0338 & -0.0123 \\
\hline $\begin{array}{l}\text { Burr Aux } \\
-\mathrm{A} 7\end{array}$ & 5752.7529 & 5752.7511 & 5752.7520 & 5752.7371 & -0.0149 \\
\hline $\begin{array}{l}\text { Burr Aux } \\
-\mathrm{A} 8\end{array}$ & 5713.6954 & 5713.7206 & 5713.7080 & 5713.7398 & +0.0318 \\
\hline $\begin{array}{l}\text { Bur Aux } \\
-\mathrm{A} 15\end{array}$ & -------- & 5755.4581 & 5755.4581 & 5755.2996 & -0.1585 \\
\hline
\end{tabular}

dome that is roughly 100 by $200 \mathrm{~m}$ in map view. The size of this block is estimated based on ground cracks that are present in the 1986 Lava Dome (Fig. 3). Measurements to the other benchmarks on the summit dome complex as well as some short EDM measurements made across the summit dome complex in 1988, 1989, 1993, and 1994 indicate that other portions of the summit dome complex are stable. The change in distance between W. Aug and A8 $(15.9 \mathrm{~cm})$ is larger than expected, while changes in line length between Burr Aux and A8 during the same period is only $3.18 \mathrm{~cm}$ (Table 2). Until A8 is resurved we are uncertain as to whether this change is the result of a data reduction error, local instability, or some other type of blunder. The large apparent changes between S. Aug. - A12 $(5.1 \mathrm{~cm})$ and Mound - A4 $(6.9 \mathrm{~cm})$ are also difficult to explain as other measurements to these marks show little change (Table 2). The most likely explanation for these discrepancies would be systematic or random survey errors as described by Savage and others (1996). 


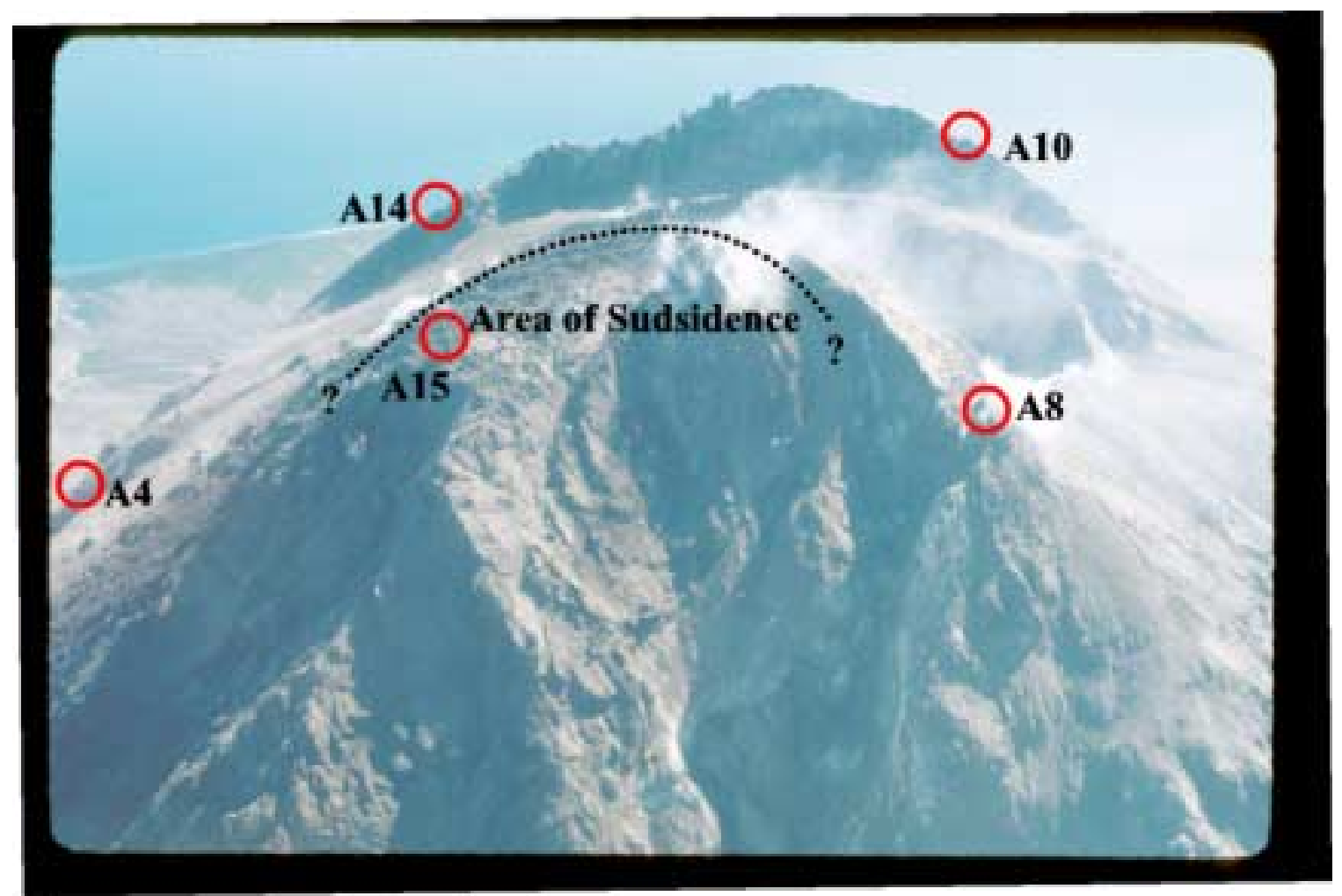

Figure 3. Aerial oblique of the north side of the summit dome complex of Augustine Volcano on August 24, 1987 showing the area of subsidence and the locations of benchmarks used in the 2000 survey. Dotted line notes position of ground cracks thought to define the portion of the 1986 lava dome that is subsiding. GPS measurements indicate this area is subsiding at roughly $7 \mathrm{~cm}$ per year. Locations of benchmarks visible in this photograph are also noted.

\section{Conclusions and Recommendations}

Based on results from the 2000 GPS survey of Augustine Volcano we formulate the following conclusions and recommendations:

1) A complete island wide survey of 22 benchmarks now serves as a baseline to monitor future deformation. This network is tied to two additional marks on the western shore of Cook Inlet.

2) Benchmark A10 has become unstable since it was installed in 1988. This mark should be replaced by another mark on a more stable portion of the 1964 lava dome during future surveys.

3) Benchmark A15 is located on a portion of the 1986 lava dome that is subsiding and moving slowly to the west. The rate of this subsidence is roughly $8 \mathrm{~cm}$ per 
year. We attribute this movement to a large $(\sim 100 \times 200 \mathrm{~m})$ landslide block on the northern edge of the 1986 lava dome. At least one additional mark should be installed in the vicinity of A15 to provide additional monitoring of this area.

4) Based on a comparison of available EDM and GPS data, no pattern of displacements that could be attributed to magmatic activity is apparent at Augustine Volcano for the period from 1988 to 2000 within the precision and accuracy of our measurements.

5) Offset benchmarks established in 1995 should be tied into main stations during the next survey to provide nearby reference for stability studies and to allow comparison of results from the 1995 GPS survey. This is especially important for the offset mark near A10.

\section{References Cited}

Miller, M. M., D.J. Johnson, C.M. Rubin, H. Dragert, K. Wang, A. Qamar, and C. Goldfinger (2001), GPS-Determination of along string variation in Cascadia margin kinematics: Implications for relative plate motion, subduction zone coupling, and permanent deformation, tectonics, v. 20, $160-174$.

Miller, T.P., R.G. McGimsey, D. H. Richter, J.R. Riehle, C.J. Nye, M.E. Yount, and J. A. Dumoulin, (1998) Catalog of historically active volcanoes of Alaska, U.S.G.S. Open-file Report 98-582, 104 p.

Murray, T.L., E. T. Endo, E.Y. Iwatsubo, and D. Dzurisin, (1996), A real-time radio telemetered GPS network for short baseline applications (abstract), EOS Trans, v. 77. p. 146.

Power, J. A. and E. Y. Iwatsubo, (1998) Measurements of Slope Distances and Zenith Angles at Augustine Volcano, Alaska, 1986, 1988 and 1989, U.S. Geological Survey Open File Report, 98-145, 17 p.

Savage, J.C., Lisowski, M., and Prescott, W.H., 1996, Observed discrepancy between Geodolite and GPS distance measurements, Journal of Geophysical Research, v. $101,25,547-25,552$. 


\section{Appendix A: Locations of benchmarks on and in the vicinity of Augustine Island.}

The geodetic coordinates listed in this appendix are those determined by GPS during the August $3-8,2000$ survey. Elevations are radius height referenced to IRTF97. Power and Iwatsubo (1998) give photographs and descriptions of all marks established on Augustine Island between 1986 and 1989. Photographs included here are only for marks surveyed for the first time during the 2000 survey.

Benchmarks A1 through A18 (there are no marks A13, A16 or A17) are $9.5 \mathrm{~cm} \mathrm{(3.75}$ inch) bronze caps which are labeled US Department of Interior - Geological Survey, Cascades Volcano Observatory - Vancouver Washington . Measurements to each of these marks are made to a central stamp that is punched within a $1 \mathrm{~cm}(0.39$ inch $)$ square in the center of the mark. The exceptions to this are marks A5 which is $6.5 \mathrm{~cm}$ (2.5-inch) plain brass cap with a central mark, and A18 which is a $9.5 \mathrm{~cm}$ (3.75 inch) bronze cap engraved National Earthquake Hazard Reduction Program with a central mark. Benchmarks Kamishak, Mound, South Augustine, West Augustine, Burr, and Step were established prior to 1986 and original descriptions can be obtained from the National Geodetic Survey. Burr Auxiliary is a plain brass cap that was established in 1973 and located by NOAA.

West Augustine - $(\mathbf{1 5 3 . 5 4 3 3 W} 59.3844 \mathrm{~N} ; 44.029 \mathrm{~m})$. The benchmark is located on the highest mound on the west island of Augustine. The top of the knoll is covered with rocks, boulders, and grass. Thick trees cover the sides of the mound. The benchmark is $1.5 \mathrm{~m}$ ( $5 \mathrm{ft}$.) south of the top of the mound on a rock outcrop. The benchmark is stamped "WEST AUGUSTINE", but it is marred and very faint. During the summer of 2000 it was possible to land a helicopter about $6 \mathrm{~m}$ (20 ft.) east of the mark.

South Augustine - $(\mathbf{1 5 3 . 5 2 3 4 W}$ 59.3232N $28.6476 \mathrm{~m})$. The benchmark is located on the southwest portion of Augustine Island. The mark sits on a tall grass-covered sand dune that runs parallel to the shore, and is approximately $69 \mathrm{~m}(225 \mathrm{ft}$.) northwest and upslope from an old shack (which had collapsed by summer 2000). To the north of the ridge are three large shallow pools. A wooden platform is located $9 \mathrm{~m}(30 \mathrm{ft}$.) west of the mark. The benchmark is a brass disk on a $5 \mathrm{~cm}$ (2-in.) pipe that has been driven flush with the ground. The benchmark is stamped "S AUGUSTINE 2 1964". There are also two reference marks in $5 \mathrm{~cm}$ (2-in.) pipes that protrude about $46 \mathrm{~cm}$ (18 in.) above ground. These are stamped "S AUGUSTINE 2 NO 2 1964", and "S AUGUSTINE 2 NO 3 1964".

Kamishak - $(153.4365 W 59.34565 N 530.828 \mathrm{~m})$. The benchmark is located on a prominent knoll along a south trending ridge on the upper south slope of Augustine

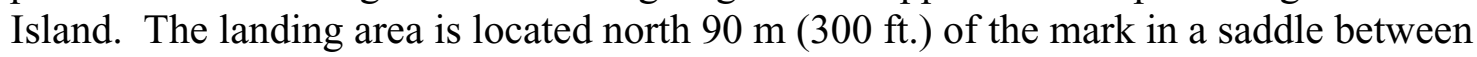
the base of the knoll and the beginning of the steep slope towards the top of the volcano. The benchmark is on a boulder on top of the knoll that is flush with the ground. It is stamped "KAMISHAK 1946". A second reference mark is cemented to a boulder several meters to the south. 
Mound - (153.3550W 59.3706N $118.2671 \mathrm{~m})$. The benchmark is located on the largest prominent hill on the east side of Augustine Island. The helicopter landing area is located to the west and down slope at the base of the hill in a flat area. The benchmark is stamped AUGUSTINE 190846.

Burr (153.4224W 59.4179N 27.8131 m). This station is located atop a $15 \mathrm{~m}(50 \mathrm{ft}$.) high grass covered hill (hummock) that forms a small island just off the north shore of Augustine Island (fig. 4). In 2000 a sand and gravel spit connected the island to Augustine during low tide. This mark was originally established in 1913 and several references marks can be found nearby. Approach the benchmark with care as eagles frequently nest on this small island.

Burr Auxiliary (153.4224W 59.4118N 27.5035) The benchmark is located on a low ridge on the northern shore of Augustine Island. It is in a low-lying outcrop just west of the existing Burr Point Hut. The benchmark is on the lip of the hill just southwest of the entrance of the hut. The mark is a plain brass cap with no markings.

STEP (153.7648W 59.4343) The benchmark is on the highest point of Step Mountain that is about 13 miles west of the summit of Augustine Volcano (fig. 5). This mark was originally established in 1913, and several reference marks and bolts can be found nearby. Helicopter can be landed in several spots just below the mountain s summit.

A1 - (153.4378W 59.3815N 355.1804 $\mathrm{m})$. The benchmark is located on a prominent lava flow on the northwest side of Augustine Island. The mark can be found just downslope from the AUL seismic station antenna and almost directly on top of the AUL seismometer. Helicopter landing is upslope from the seismic site. Benchmark is stamped A1 1988 .

A2 - (153.4245W 59.3666 $879.2775 \mathrm{~m})$ The benchmark is located on a prominent knob on the northeast side of volcano about $46 \mathrm{~m}(150 \mathrm{ft}$.) along the ridge connecting knob and volcano. Helicopter landing is on top of prominent round knob. Benchmark is stamped A2.

A3 - (153.4245W 59.3676 $865.1927 \mathrm{~m})$ The mark is located on a prominent round knob on the northeast side of the volcano. The helicopter landing site is on top of the knob, the same location as for mark A2. The benchmark is located approximately $46 \mathrm{~m}$ (150 ft.) NNW and $9 \mathrm{~m}(30 \mathrm{ft}$.) lower than landing site. Mark is on rock outcrop, which stands up about $0.8 \mathrm{~m}$ ( $2.5 \mathrm{ft}$.). A rock cairn was built nearby and painted orange when benchmark was installed. Benchmark is stamped A3 1988 .

A4 - (153.4234W59.3623N $1055.7675 \mathrm{~m})$. The benchmark is located about $30 \mathrm{~m}(100$ ft.) above seismic station AUP, on a small outcrop of rock just above flat bench. The helicopter landing is on the flat bench. The benchmark is stamped A4, but the stamping was very faint in 2000. 
A5 - (153.5192W 59.3781 $28.9097 \mathrm{~m})$. The benchmark is located north of the Augustine West Lagoon Hut, about three quarters of the way from the hut to the break in slope above the lagoon. It is on a large flat rock located northeast of the trail leading from the hut to the lagoon. It is on top of the bluff overlooking the northeast part of the lagoon. The mark is a plain brass mark with a center punch and is stamped A5 1988 .

A6 - (153.4373W 59.3711N 677.1183m ). The benchmark is located on the upper slope of the prominent ridge on the northeast side of Augustine Island. The mark is located on a low red/yellow outcrop flush with the ground $53 \mathrm{~m}$ (175 ft.) N10E of the telemetered GPS station called Windy. Helicopter landing is easy in small saddle between main volcano and lava flow just to the south of telemetered GPS site. Benchmark is stamped A6 1988 .

A7 - (153.4456W 59.3630N 900.5171 $\mathrm{m})$. The benchmark is located on an outcrop on the western edge of a prominent lava dome $($ Dome $\mathrm{H})$ on the west side of the volcano. Seismic station AUH is approximately $23 \mathrm{~m}(75 \mathrm{ft}$.) northwest of the mark. From the mark West Augustine, South Augustine, and Burr Auxiliary benchmarks can all be seen. Helicopter landing is easy on many flat spots above the mark. Benchmark is stamped A7 1988 .

A8 - (153.4330W 59.3624N 1218.5432 $\mathrm{m})$. The benchmark is on top of the 1935-dome remnant on northwest side of summit dome complex. The best helicopter landing site is on the prominent flat area on west side of the volcano several hundred $\mathrm{ft}$. below the summit. To ascend to the mark you must climb up the steep south face of the 1935 dome remnant. This climb is very steep (a class 5 rock climb) and requires the use of both hands and feet. Benchmark is stamped A8 1988 .

A9- $(153.4139 \mathrm{~W} 59.3230 \mathrm{~N} 40.8022 \mathrm{~m})$. The benchmark is located on the southwest portion of a point of land extending from the southern shore of Augustine Island. Landing is in a broad flat grassy area just north $(9-12 \mathrm{~m})(30-40 \mathrm{ft}$.) of the prominent outcrop containing the mark. The benchmark is located on the upper north side of the largest outcrop in the area. An old, unused, benchmark GRUB is located $\sim 90 \mathrm{~m}(300$ ft.) west of A9 on a smaller outcrop. Benchmark is stamped A9 1988 .

A10 - (153.4327W 59.3593 $1243.1684 \mathrm{~m})$. The benchmark is high on the south rim of the 1964-dome remnant. The mark is about $27 \mathrm{~m} \mathrm{(90} \mathrm{ft.)} \mathrm{east} \mathrm{of} \mathrm{a} \mathrm{prominent} \mathrm{notch} \mathrm{in} \mathrm{the}$ south rim, where AUS seismic station is located. Traveling east to west this is the first notch that can be easily climbed onto the south face of the volcano. You must climb up the outside of the 1964 rim from the notch to reach the benchmark. Landing site is in the broad flat area within the $1963 \mathrm{rim}$. The benchmark is on a rock outcrop back 1.5 to $3 \mathrm{~m}$ $(5-10 \mathrm{ft}$.) from the edge of the rim. When this mark was visited in 2000 a series of enechelon cracks had opened behind the mark. Benchmark is stamped A10 1988 .

A11 - (153.3867W 59.3486N 216.8437 $\mathrm{m}$ )The benchmark is located on a low ridge of large boulders on the southeast side of Augustine Island. The benchmark is on a flattopped boulder projecting up $0.9-1.5 \mathrm{~m}(3-5 \mathrm{ft}$.) that forms a flat ledge. The 
benchmark is approximately $9 \mathrm{~m} \mathrm{(30} \mathrm{ft.)} \mathrm{upslope} \mathrm{from} \mathrm{the} \mathrm{largest} \mathrm{boulder} \mathrm{on} \mathrm{the} \mathrm{ridge.}$ Benchmark is stamped A11 1988 .

A12 - (153.4377W 59.3586N $1100.5371 \mathrm{~m})$. The benchmark is on a prominent rock knob on the southwestern shoulder of Augustine Volcano. The mark is on the southernmost remnant of the 1935 dome. The helicopter landing is well above the benchmark in the flat area between the 1964, 1986, and 1935 domes (same landing site as used for A8). From the landing site descend several hundred $\mathrm{ft}$. to the south to reach the benchmark. Benchmark is stamped A12 1988 .

A14 - (153.4258W 59.3593N $1179.8655 \mathrm{~m})$. The benchmark is high on the east end of the 1964 dome remnant that makes the present crater rim of the volcano s rim and summit. To reach the mark traverse around the northeast end of this rim on the tephra ramp from the 1986 lava dome. Climb up talus onto the east face of the volcano (outside

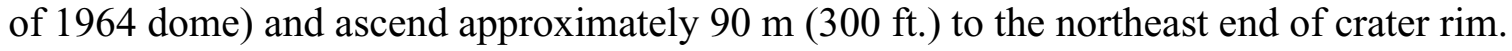
The benchmark is on a rock outcrop projecting approximately $2 \mathrm{~m}(6 \mathrm{ft}$.) up that is set back roughly $3 \mathrm{~m}$ (10 ft.) from the crater edge. The climb is fairly exposed. Bearings from the mark to several points are N33E to highest pinnacle, N75E to BM Mound, and S7E to BM A9. Additional cement was added to this mark in 2000. Benchmark is stamped A14 1988.

A15 - (153.4282W 59.3617N 1224.1582 m). The benchmark is on a nondescript boulder about $46 \mathrm{~m}$ (150 ft.) east of the Domo tilt meter site and dome helicopter landing area. Benchmark is stamped A15 1988 .

A18 - (153.5877W 59.5700N 394.8782 m). The benchmark is located in a prominent saddle above Ursus Head on the western side of Cook Inlet (fig. 6). The mark is in broad flat area of exposed bedrock that is free of brush and offers easy helicopter access. The benchmark is a $9.5 \mathrm{~cm}$ (3.75 in.) diameter brass cap that is labeled U.S. Department of Interior National Center for Earthquake Research, Menlo Park. Calif. Geological Survey. Measurement is to the center stamp mark in the $1 \mathrm{~cm}(0.39$ in.) diameter square in center of mark. Benchmark is stamped A18.

LU01 - (153.4273W 59.3859N 246.193 m). The station is a PÆK nail driven into the top of a boulder about $8 \mathrm{~m}(26 \mathrm{ft}$.) across that is $15 \mathrm{~m}$ (49 ft.) west of the north corner of the largest boulder on the 1976/1986 pyroclastic debris fan, at an elevation of approximately $225 \mathrm{~m}$ (740 ft.) above sea level (fig. 7). The largest boulder is easily identifiable from the hut at Burr Point and from nearby benchmark BURR. The punch in the PÆK nail is very faint, which makes centering difficult. If the punch is not visible, the center of the nail head, midway between the letters $\mathrm{P}$ and $\mathrm{K}$, can be used instead.

LU02 - (153.4250W 593719N 558.774 m). The station is a PÆK nail driven into the top of a $4 \mathrm{~m}$ (13 ft.) boulder in the upper reach of the 1976/1986 pyroclastic debris fan, near

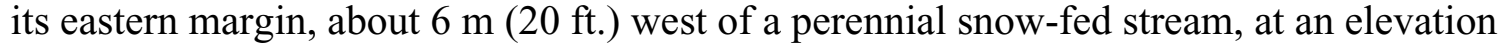
of approximately $542 \mathrm{~m}$ (1780 ft.) (figs. 8 and 9). The center punch on the head of the nail, located midway between the letters $\mathrm{P}$ and $\mathrm{K}$ should be used for centering. 


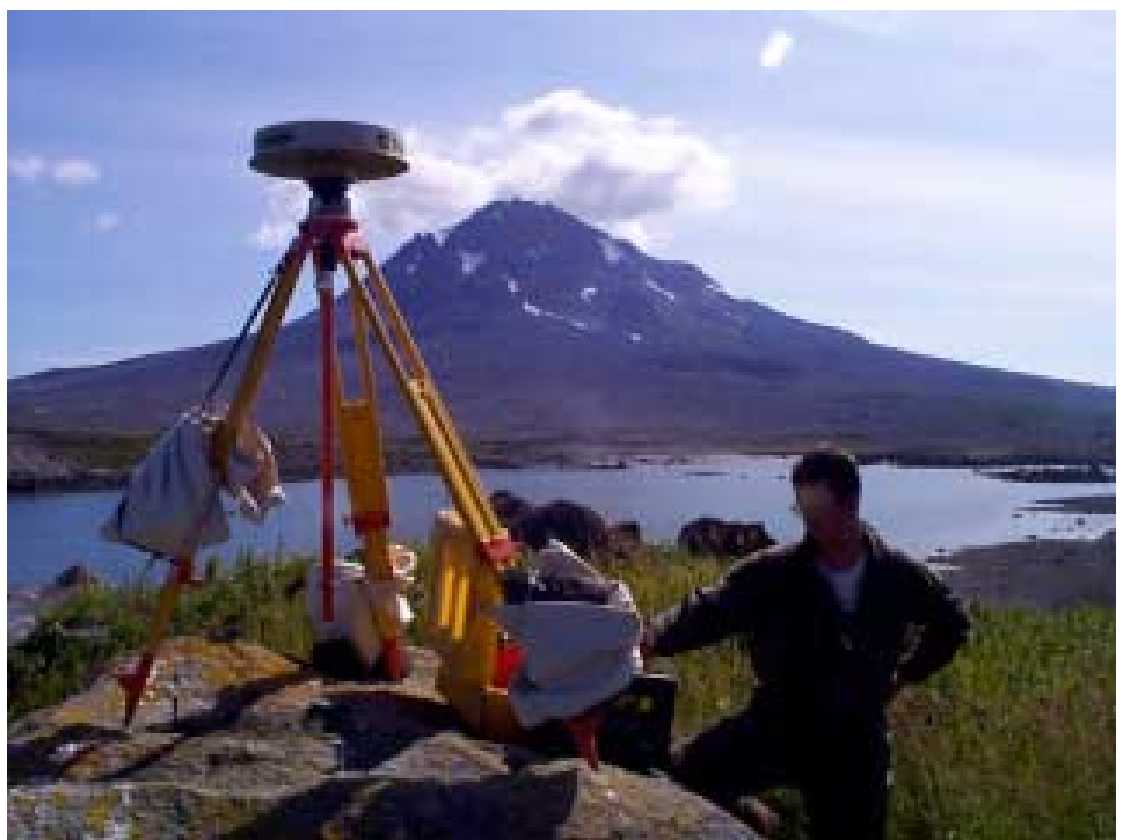

Figure 4. GPS equipment set up at benchmark BURR. This mark was originally established in 1913.

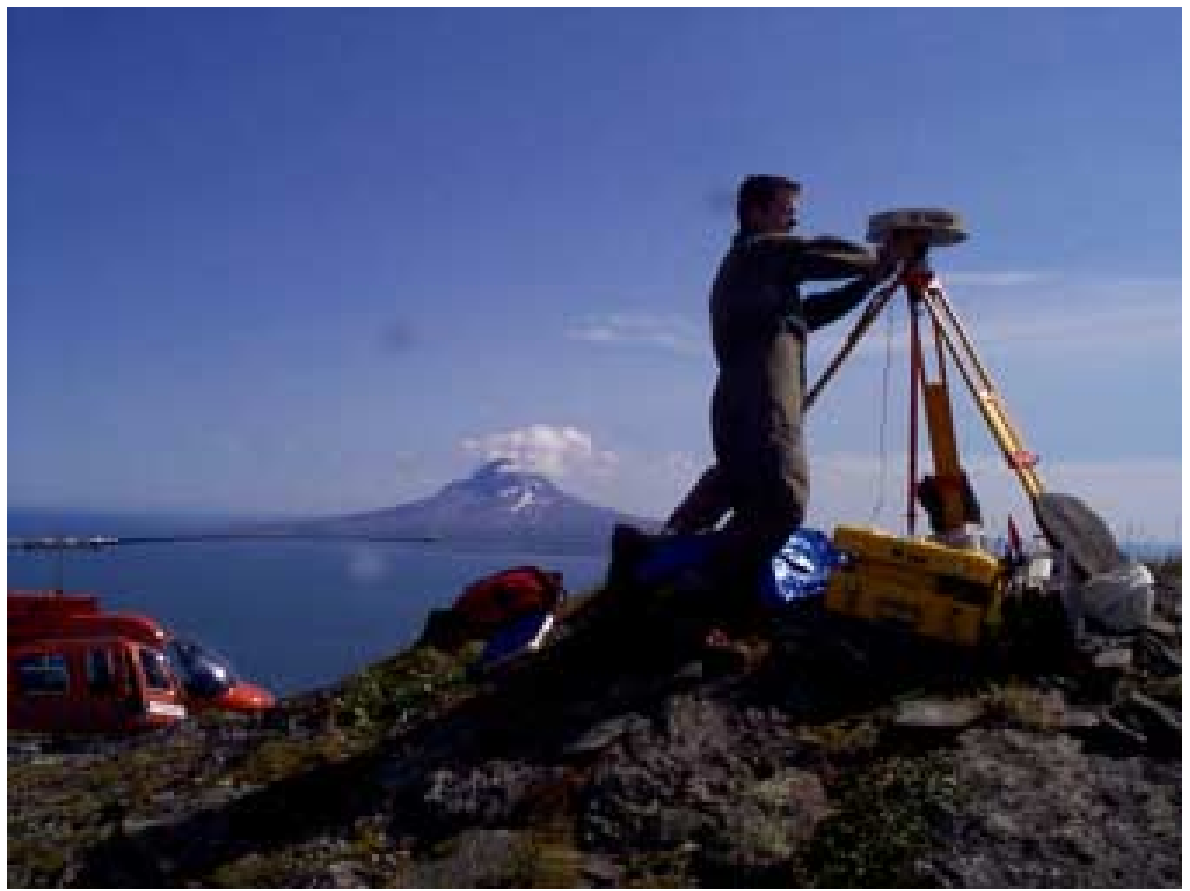

Figure 5. GPS receiver set up at benchmark Step on the western side of Cook Inlet (Fig. 1). Augustine Volcano is visible in the background. 


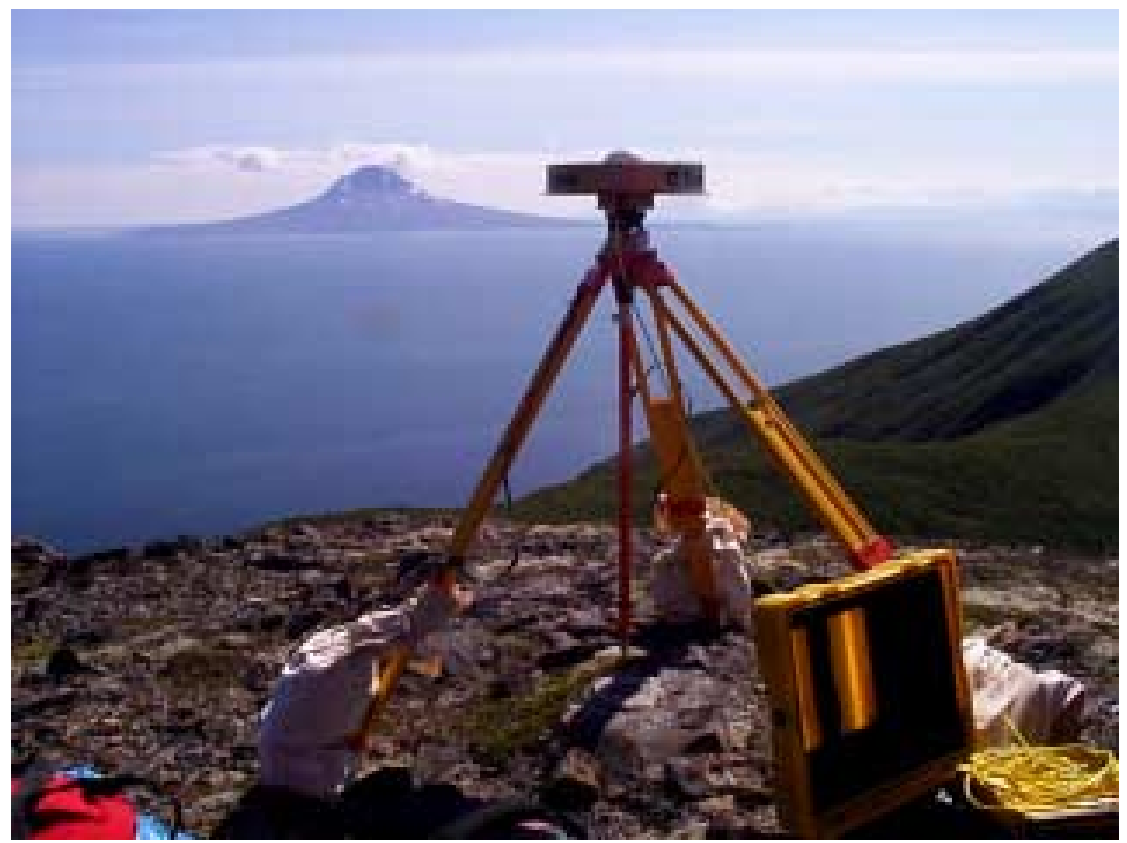

Figure 6. GPS equipment set up at benchmark A18 near Ursus Head on the western shore of Cook Inlet (fig. 1). Augustine Island is visible in the background.

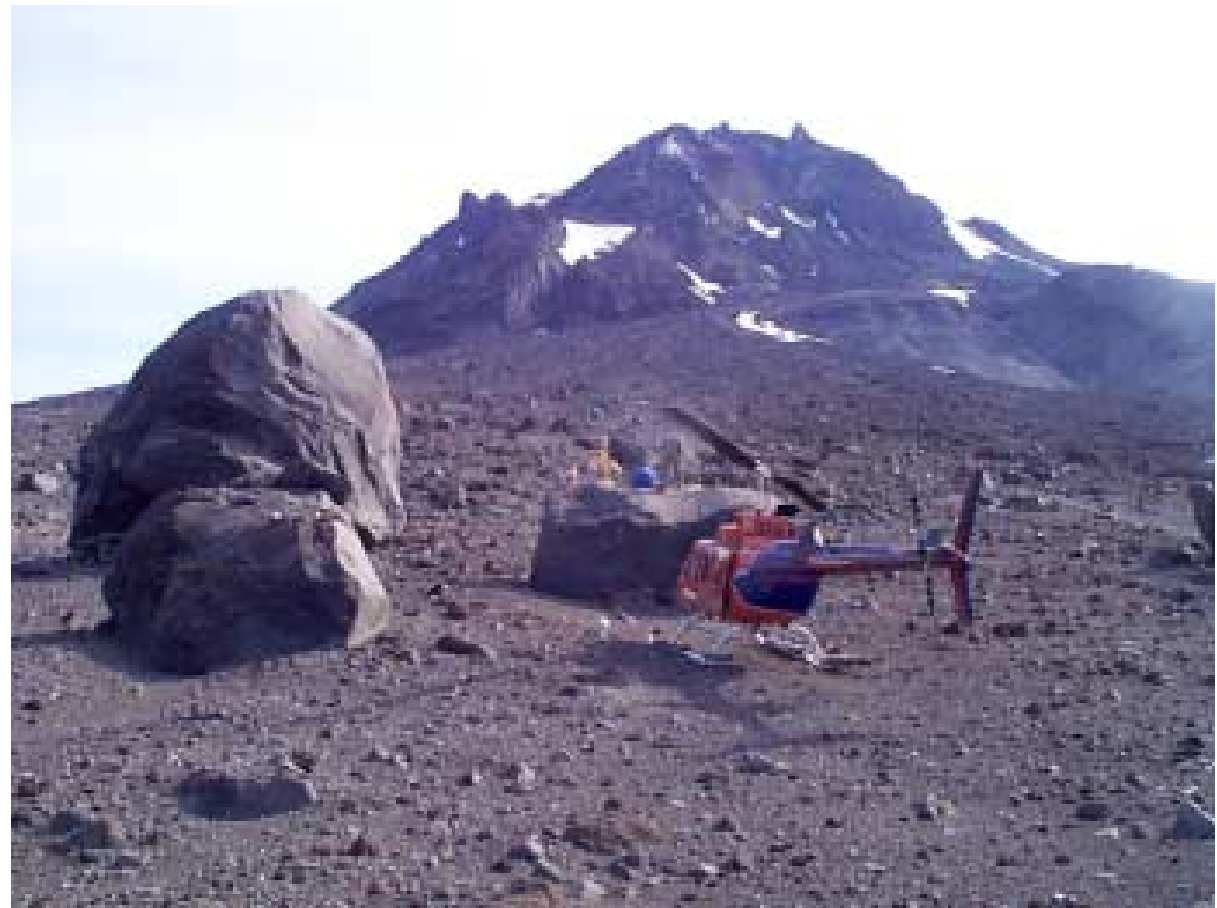

Figure 7. Tripod set up at survey mark LU01. The largest boulder on the 1976/1986 pyroclastic debris fan is visible to the left of the station. To help locate LU01, this same boulder can be identified from the hut at Burr Point. The summit of the volcano is visible in the background. 


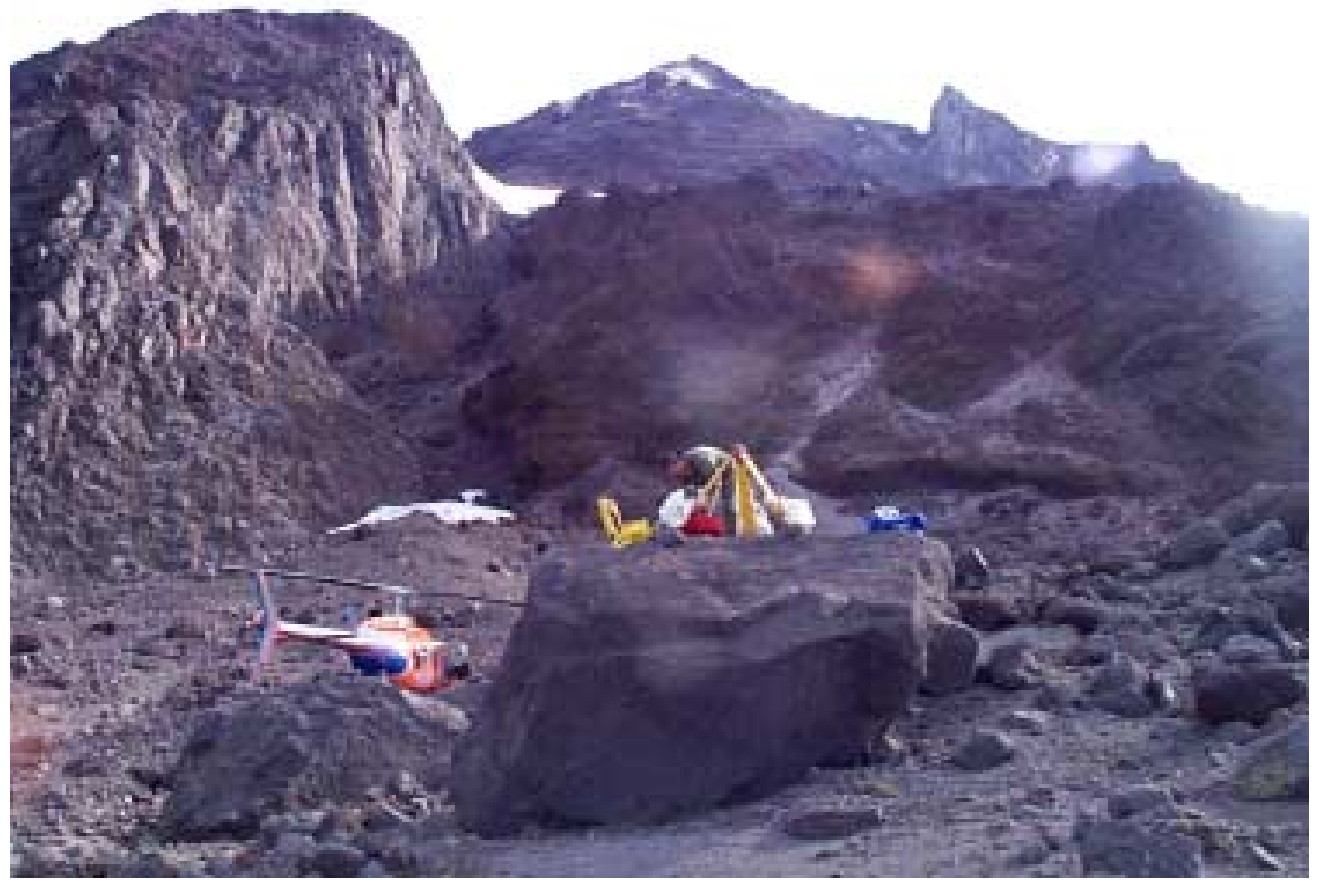

Figure 8. Survey equipment set up at mark LU02. To avoid pervasive airborne ash, the helicopter has landed in the bed of a small stream that is fed by melting snow located directly behind the station. Summit area of the volcano is visible in the background.

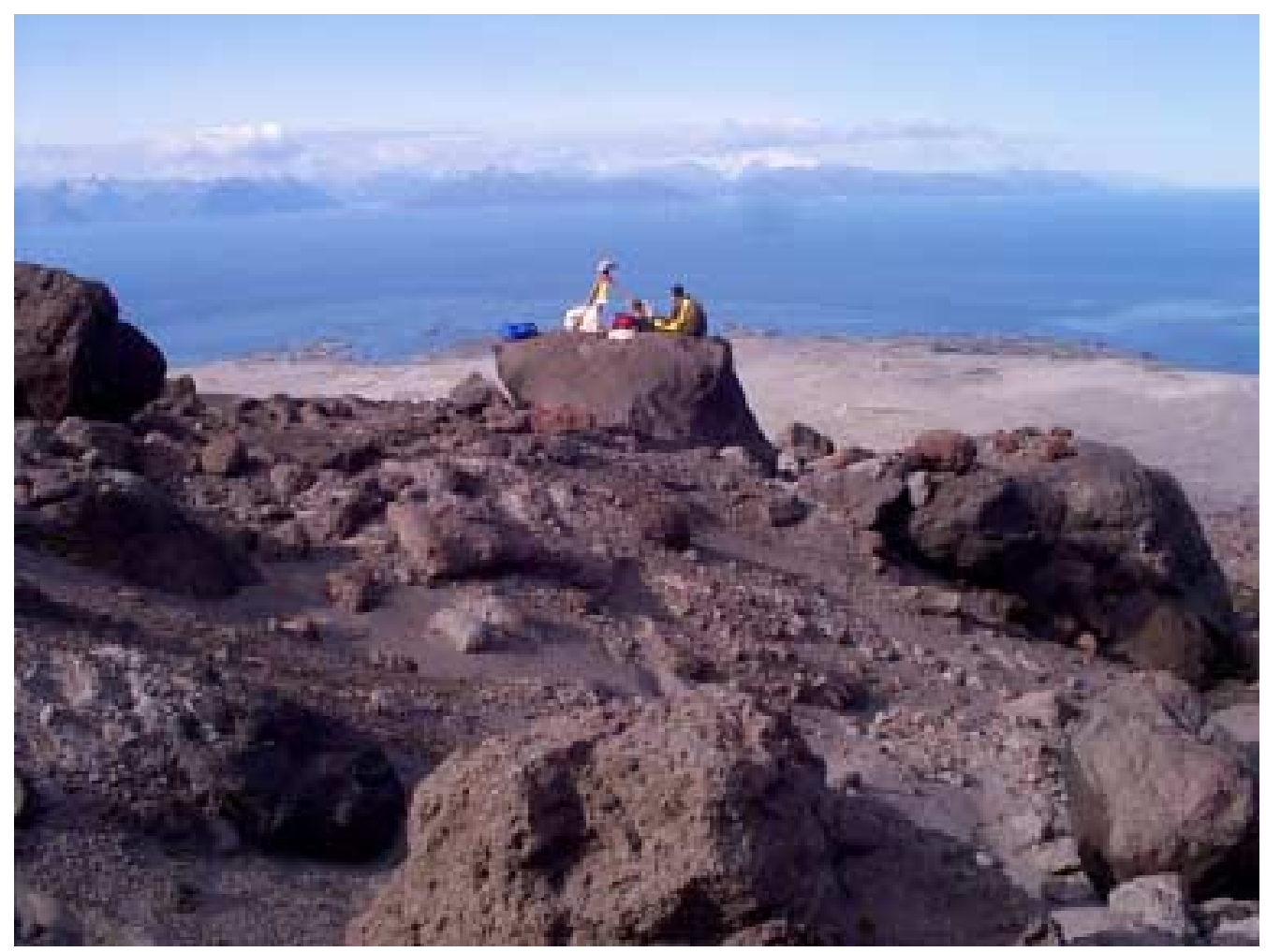

Figure 9. GPS equipment set up on station LU02. View is northward toward Burr Point, which is visible as a dark portion of the shoreline to the right of the station in this view. 
Appendix B: Table contains name of benchmark in Augustine geodetic network, site name as entered in the GPS receiver and station name as represented in USGS gp database.

\begin{tabular}{|c|c|c|}
\hline Benchmark & Site Name & gp Database \\
\hline A1 & $00 \mathrm{a} 1$ & ag01 \\
\hline $\mathrm{A} 2$ & $00 \mathrm{a} 2$ & ag02 \\
\hline A3 & $00 \mathrm{a} 3$ & ag03 \\
\hline A4 & $00 \mathrm{a} 4$ & ag04 \\
\hline A5 & $00 \mathrm{a} 5$ & ag05 \\
\hline A6 & $00 \mathrm{a} 6$ & ag06 \\
\hline A7 & $00 \mathrm{a} 7$ & ag07 \\
\hline A8 & $00 \mathrm{a} 8$ & ag08 \\
\hline A9 & $00 \mathrm{a} 9$ & ag09 \\
\hline A10 & 0a10 & ag10 \\
\hline A11 & 0a11 & ag11 \\
\hline A12 & 0a12 & $\operatorname{ag} 12$ \\
\hline A14 & 0a14 & ag14 \\
\hline A15 & 0a15 & ag15 \\
\hline A18 & 0a18 & ag18 \\
\hline West Augustine & waug & agwe \\
\hline South Augustine & saug & agso \\
\hline Mound & moun & agmd \\
\hline Burr & bur2 & agbr \\
\hline Burr Auxiliary & burr & agbx \\
\hline Step & step & agst \\
\hline Lu1 & lu01 & agl1 \\
\hline Lu2 & lu02 & agl2 \\
\hline
\end{tabular}

